\title{
Nexus Generation Job Creators: A Review of Generational Attributes and Opportunities
}

\author{
Nur Afiqah Binti Mohammad Ishak,Nurazariah Binti Abidin and \\ Jegatheesan Rajadurai
}

College of Business \& Accounting, Universiti Tenaga Nasional, Kampus Sultan

Haji Ahmad Shah, Pahang, Malaysia

Correspondence should be addressed to: Afiqah Mohammad; afiqah.mohammad3@gmail.com

Received date: 4 August 2017; Accepted date: 22 November 2017; published date: 28 January 2019

Academic Editor: Marlita Mat Yusof

Copyright (C 2019. Nur Afiqah Binti Mohammad Ishak,Nurazariah Binti Abidin and Jegatheesan Rajadurai. Distributed under CreativeCommons CC-BY 4.0

\begin{abstract}
The development of modern business technology provides an opportunity for future virtual entrepreneurs to start-up a product and build their very own empires at a very low cost and no border interactivity with the consumer because the information is easily accessible. The generation with the most potential to become future virtual entrepreneurs is the Nexus generation. This paper aims to present reviews of Nexus generation behaviour and analyze the reasons why the Nexus generation has the potential to become virtual entrepreneurs. Today is the era of technological advancement. Many researchers in the Social Sciences claim that Nexus is the first generation of this era of technological growth. They are well educated, confident, achievers who take advantage of opportunities and are highly technologically savvy. The stumbling blocks are the unemployment rate among the Nexus generation and the lack of opportunities to become entrepreneurs. Therefore, the purpose of this study is to investigate the entrepreneurial potential of the present Nexus generation graduate and to determine the qualities which contribute to them becoming virtual entrepreneurs. This study is significant because it will contribute to the development of Malaysia's growth in line with the National Strategic 2015 set by the Government
\end{abstract}

Keywords: Nexus generation, virtual entrepreneur, graduates, Malaysia

Cite this Article as: Nur Afiqah Binti Mohammad Ishak,Nurazariah Binti Abidin and Jegatheesan Rajadurai (2019)," Nexus Generation Job Creators: A Review of Generational Attributes and Opportunities ", Journal of Southeast Asian Research, Vol. 2019 (2019), Article ID 896281, DOI: 10.5171/2019.896281 


\section{Introduction}

Every developing country has its own vision of becoming a developed country. Malaysia is no exception. Malaysia's Vision 2020, launched in 1991, envisages Malaysia as a fully developed country economically, politically, socially, spiritually, psychologically and culturally by 2020 (By, Prime, The, \& Rakyat, 2016; Yunus, 2006). In order to achieve this vision, the government has implemented several initiatives such as the National Blue Ocean Strategy (NBOS) (Economic Planning Unit, 2015). The National Blue Ocean Strategy (NBOS) involves strategic planning and operations for positive, high impact programs and services for the public. They are to be low cost to assemble and should be able to be executed quickly in order to assist the nation's growth (Economic Planning Unit, 2015; Laird, 2015).

The National Blue Ocean Strategy is divided into many strategies including creating more jobs for Nexus generation graduates. Aligned with this, the Ministry of Human Resources has provided an automated online job matching service called JobsMalaysia (United Nations, 2002). JobsMalaysia was previously known as the Job Clearing System, an electronic labour exchange (ELX). Through JobsMalaysia, the job seekers are able to search for suitable job vacancies publicly for free through the facilities of the Ministry of Human Resources (Laird, 2015). However, even though it acts as a one-stop centre for labour market information, the objective of the system is to improve and ensure manpower utilization. It optimises opportunities for job seekers but it does not apply to fresh graduates, especially from the Nexus generation (Laird, 2015; Zulkifli, Omar, \& Rajoo, 2016). Research has found that there are several reasons why companies do not hire fresh graduates. Below, Figure 1 has been adapted from http://hk.jobsdb.com/hk/en/staticcontent/h iring-survey/2013/Q2-hiring-index/freshgraduate-employment.htm (Zulkifli et al., 2016).

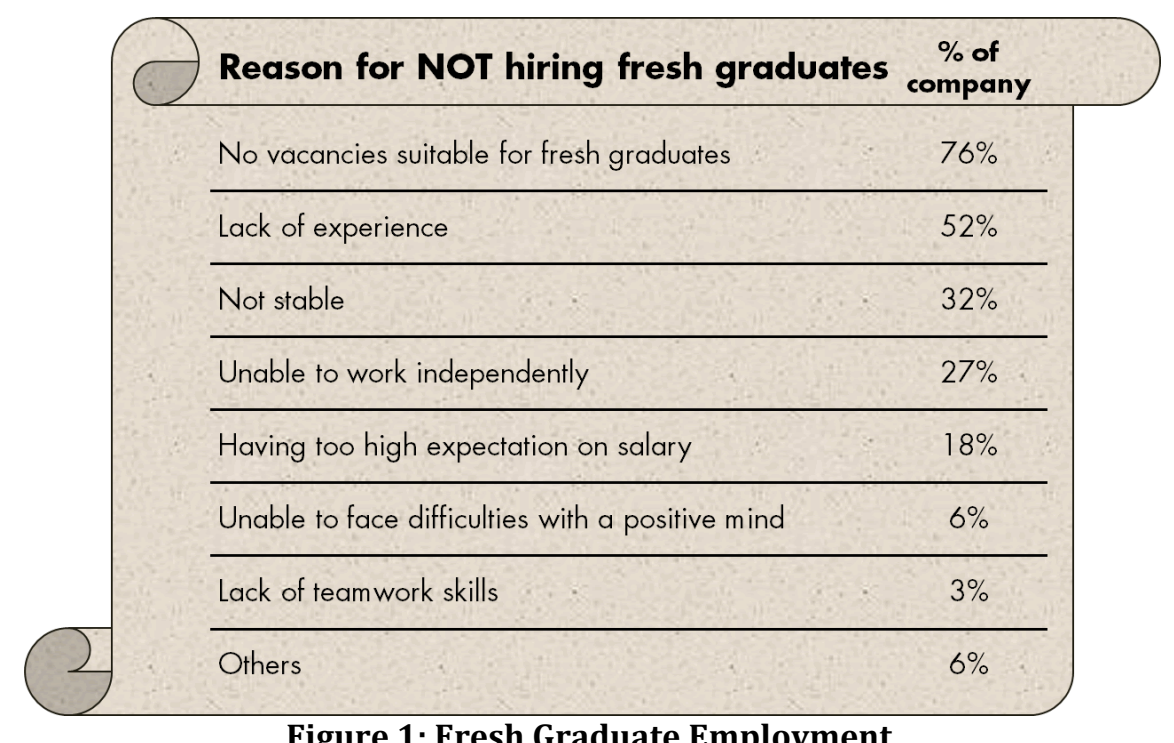

Figure 1: Fresh Graduate Employment

Source: jobsDB, 2013

(http://hk.jobsdb.com/hk/en/staticcontent/hiring-survey/2013/Q2-hiring-index/fresh-graduateemployment.htm)

Nur Afiqah Binti Mohammad Ishak,Nurazariah Binti Abidin and Jegatheesan Rajadurai (2019), Journal of Southeast Asian Research, DOI: 10.5171/2019. 896281 
The reason that received the highest percentage for not hiring fresh graduates was because no vacancies were available (32\%) (Fresh Graduate Employment, 2013). Because of these reasons, many Nexus generation graduates are unemployed. Department of Statistics Malaysia reveals that, of the total unemployed labour force,
$16.7 \%$ of 65,500 graduates were unemployed (Zulkifli et al., 2016). The number of unemployed graduates increases throughout the year. Unemployment among local university graduates has become a big problem in Malaysia. Figure 2 shows the unemployment rate in Malaysia from April 2016 until Jan 2017.

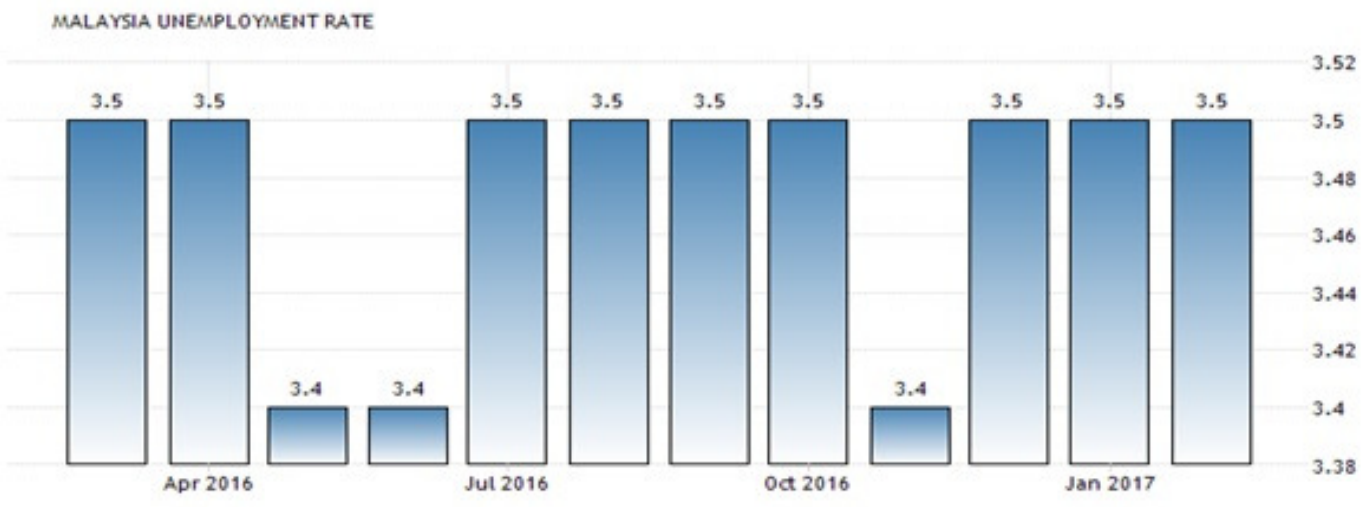

Figure 2: Unemployment Rate in Malaysia

Source: Department Statistic Malaysia, 2017

(http://www.tradingeconomics.com/malaysia/unemployment-rate)

The asymmetrical growth of job opportunities and youth population presents a great challenge to many nations. At the same time, driven by the growth of high Internet usage and the disposable income in recent years, digital businesses are also becoming a hot topic globally. Empowering youth through entrepreneurship initiatives is seen as a feasible option to ensure the development of a balanced and stable economy. Hence, the Malaysian government support for young entrepreneurs' development is very encouraging. Various services such as the business advisory, loans and funding have been offered to stimulate the interest of these young people and to encourage them to establish their own start ups (http://www.cedar.my/publications- store/64-new-gen-entrepreneur-inmalaysia-a-vibrant-economic-force.html).

\section{Objectives}

Towards 2020, The National Youth Policy is part of the Government's policy for greater democratic participation and impartial economic and social progress for all (Secretariat, 2015). The Government aims to support youth who form the Nexus generation, and is steadfast in its aim to execute the new policy for youth over the five-year time frame 2015-2020 (By et al., 2016; Laird, 2015). Hence, the main objectives of this conceptual paper are: 
i. To identify the Government plan to develop job creators among the Nexus generation;

ii. To explore the characteristics and behaviours that make Nexus generation the best choice over other generations to become future virtual entrepreneurs; and

iii. To identify the reasons for unemployment in the Nexus generation.

\section{Job Creators}

Nowadays, all developing countries have the issue of unemployment among fresh graduates. This makes it hard for the government to sustain the nation's economy (Yunus, 2006). The era of globalisation has made the labour market more vibrant with rapid changes in technology and the changing needs of companies (Lenhart, Purcell, Smith, \&Zickuhr, 2010; Zulkifli et al., 2016). The economy of a developing country like Malaysia is directly connected to the rate of unemployment. The Malaysian economic recession in 1997 led to a massive downsizing of companies. It is a lesson that needs to be kept in mind (Zulkifli et al., 2016). The unemployment rate increased rapidly and individuals were left high and dry. During that period, entrepreneurship managed to sustain the economic lives of some of these individuals by providing an alternative source of income (Petkova, 2009; Zulkifli et al., 2016). Entrepreneurship is still needed to create new jobs as large firms are no longer creating jobs as they once did (M. Hoppe, E. Union, 2016). Large organisations are downsizing to cut costs in order to remain competitive in the market. In August 2013, the unemployment rate increased by $3.1 \%$ a month compared with previous months - 3.0\% in July and in August 2012 only 2.7\% (Yunus, 2006; Zulkifli et al., 2016).

Due to the issue of unemployment among local university graduates in Malaysia, the government would like to see the youth sector becoming self-employed as entrepreneurs. The Government addressed this issue by changing the position of "job seeker" into "job creator" through the National Blue Ocean Strategy (NBOS) (Laird, 2015; By et al., 2016). The Government's plan is a final five-year strategic development through the Eleventh Malaysia Plan to ultimately achieve Vision 2020 (Economic Planning Unit, 2015). The strategic development plan consists of six strategic thrusts. One of the main focuses of the six strategies is for youth, who are the nation's hope for the future as well as being an important asset. By implementing the new National Youth Policy, the Malaysian government hopes to encourage the Nexus generation through capacity building, education, skills training, entrepreneurship, sports and volunteerism (Secretariat, 2015; United Nations, 2002).

Through the National Youth Policy, the government and the Malaysian Global Innovation and Creativity Centre (MaGIC) established a one-stop centre that provides a comprehensive ecosystem for entrepreneurs to develop the businesses and services required by entrepreneurs (New Straits Times, MaGIC Empowers Nation's Economy, 2015). Entrepreneurship is needed to create new businesses while simultaneously creating new jobs (M. Hoppe, E. Union, 2016). The Malaysian Global Innovation and Creativity Centre (MaGIC) encourages startups by entrepreneurs to market their products abroad using online technologies such as websites, social media and mobile applications (New Straits Times, MaGIC Empowers Nation's Economy, 2015).

In addition, the Government implemented entrepreneurship education because of the relationship between regional trade and industry development through new ventures and job creation (Entrepreneurship, 2016). The strong emphasis on economic success and job creation has indeed moved entrepreneurial education into a top position at the higher education level (Entrepreneurship, 2016; Secretariat, 2015). Malaysia's Higher Education Minister Datuk Seri Idris Jusoh stated that future graduates of institutes of higher learning will no longer 
need to depend on government or private sector jobs but will be able to create jobs for themselves and others (News Malaysia, 2015). This statement came as a reply to a question regarding the future of the country's higher education system, quality of graduates, lecturers and researchers at universities (News Malaysia, 2015; Secretariat, 2015).

The introduction of this policy shows the government's emphasis on the importance of integrating entrepreneurial values and cultures among Higher Education Institutions' (HEIs) graduates. At a launch in April, 2010 by the Ministry of Education (MOE), Higher Education Entrepreneurship, it became apparent that the Development Policy is the current policy concerning entrepreneurship education. The aim of this policy is to boost the development of more holistic and well organized entrepreneurship programs (S. Shamsudin, A. Mamun, N. Nawi et al., 2016). Following the launch of the policy, the MOE as well as the HEIs gave taken a number of initiatives to implement entrepreneurial education and development to increase the number of entrepreneurs among Malaysia's younger generation.

Meanwhile, by endorsing the implementation of entrepreneurial education in the Malaysian Higher Education, as well as ensuring the aim of the Higher Education Entrepreneurship Development Policy is achieved, the Strategic Plan on Entrepreneurship Development in Higher Education (2013-2015) was launched on April, 2013 (Kementerian Pengajian Tinggi Malaysia, 2013). Specifically, the implementation of the policy aims to produce graduates from HEIs with thinking and entrepreneurial attributes as well as to increase the number of entrepreneurs among graduates who are engaged in business. This will serve as a catalyst for the achievement of an economic transformation in the country. Hence, entrepreneurship education particularly is one of the best solutions to reduce the dependency of graduates on being employed. With this in mind, it is also essential to investigate how generation evolution plays a role in stimulating job creators.

\section{Generation Evolution}

A generation can be considered a group of the population who has shared experiences and has a history that influences their thinking and behaviour (O'Keeffee, Thomson, \& Dainty, 2013; William J. Schroer Principal). Each generation shares the same experiences and they remain with them as they grow up through different stages of life even though not every individual in a generation has identical personal experiences (Lifestyle, 2011).

Researchers have referenced Jane Holroyd's Study of Generation Evolution. Baby Boomers are a generation now approaching retirement age. The Baby Boomers are those born roughly between the years 1946 and 1964 (aged 53-71) (Lifestyle, 2015). This is the generation which has had it all, raised by parents who experienced the Great Depression but then the prosperous post-war era (http://socialmarketing.org/archives/genera tions-xy-z-and-the-others). Many benefited from free tertiary education and relatively low housing costs. Generally speaking, some range from being self-obsessed to "stuck in their ways". Baby Boomers' life experiences were completely different from other generations in their attitudes, behaviors and society

(http://socialmarketing.org/archives/genera tions-xy-z-and-the-others).

Meanwhile, Generation $\mathbf{X}$ are those who were born between 1965 and1980 and are now aged 52 to 37 (Lifestyle, 2011). Generation $\mathrm{X}$ is a smaller population group than the previous Baby Boomer generation. Generation $\mathrm{X}$ is often labeled as the slacker generation and sometimes referred to as the lost generation (Moorthy, 2014; William J. Schroer Principal). This was the first generation that had lots of day care and experienced divorced parents which led 
them to being uncommitted and distracted. Generation X job hops several times. It is also known as the "why me?" generation (Lifestyle, 2011). While their parents grew up in the era of the Civil Rights movement, Generation $\mathrm{X}$ is considered as the generation that quit without trying to identify the problems or care about the social issues around them. They more likely want to keep their heads down rather than change the world. Generation X is the generation with the lowest rate of selection for participation in research compared to other generations (William J. Schroer Principal; Lifestyle, 2011; Sally Kane, 2017).

Lastly, the Nexus generation or Generation Y comprises those born between 1980s and 2000s. Nexus members are considered to be very sophisticated technology stars, resistant to most traditional marketing and sales trends because they have grown up, seen it and been exposed to it all since early childhood (Lenhart et al., 2010; O'Keefee et al., 2013; Sally Kane, 2017). Nexus members are more ethnically different, much more segmented and have grown up quickly with Cable TV channels, satellite radio, the Internet and so forth (Howe et al., 2013). The Nexus generation is not brand loyal and the rapidity of the Internet has led the group to be correspondingly flexible by varying in fashion and up to date styles and their modes of communication (Hargittai\&Hinnant, 2008; O'Keeffee et al., 2013)

\section{Nexus Generation}

The Nexus generation is a group of people that was born between 1980 and 2000 and is commonly referred to as Generation Y, the Millennials, eco-boomers or dot.com generation (San, Omar, \& Thurasamy, 2015). Nonetheless, there is much divergence and argument concerning the age range of the Nexus generation.

In 2010, Malaysia's the Nexus generation was $40 \%$ of Malaysia's population (Barford \& Hester, 2011; Howe et al., 2013; Zulkifli et al., 2016). Compared with other generations, the
Nexus generation formed the major part of Malaysia's population. Malaysia's Internet usage, as a percentage of the population, based on age, revealed that $38 \%$ were $15-24$ years old, $26 \%$ were $26-35$ years old, $23 \%$ were aged between 36 and 44 years old, $9 \%$ were from the age of 45 to 54 and 5\% were aged 55 and above (San et al., 2015). Based on those statistics, the majority of the Internet population in Malaysia was the Nexus generation with 49\% (San et al., 2015).

Past studies have explored the organizational needs of the Nexus generation because $66 \%$ of Nexus will lead the way in the future (Barford\& Hester, 2011). As a result, the organizational expectations and needs of the generation have now been well explained. The Nexus generation tends to be self-reliant, independent and requires freedom and flexibility to complete tasks at their own pace and in their own way (Howe et al., 2013; Sally Kane, 2017). They are the most technologically savvy and educated generation to enter industry (Hargittai\&Hinnant, 2008; Lenhart et al., 2010; O'Keeffee et al., 2013). The Nexus generation tends to think in a short term mode and expects direct feedback (Sally Kane, 2017). This generation is very responsible and sees work as a chance to show their skills and their significance within the organization. It is a generation that has grown up in rapidly changing surroundings in a more globalized and mobilized world and experienced technological advances such as the Internet and mobile phones (Hargittai\&Hinnant, 2008; Lenhart et al., 2010; O'Keeffee et al., 2013).

Though there has been some research done on the Nexus generation around the globe, not as much research has been done on the Malaysian Nexus generation especially research that looks into their characteristics and their learning methods (Majid et al., 2016). Some recent research includes the investigation of cultural values and career goals of the Malaysian Millennials (Maimunah \& Hoo, 2014), and employer rewards and Malaysian Millennials (Maznah 
et al., 2014). However, it is interesting to note that the few of the findings in these studies confirm that the Malaysian Nexus generation is particularly technologically savvy and that the use of web technologies is a common part of their daily routines (Majid et al., 2016). These findings confirm that the Nexus generation in Malaysia is no different from their Western counterparts in relation to technology and the use of web technologies.

\section{Key Aspects of Nexus Generation}

For the purpose of the study, the Nexus generation is considered to consist of individuals born in the 1980s and early 2000s, and are currently aged between 17 and 37 years (San, Omar, \& Thurasamy, 2015). The general definition differentiates them from the generations before them such as the Baby Boomers, Generation X and the following generation referred to as Generation Z (Sally Kane, 2017). The Nexus generation made up the largest growth sector in the labour force in the 2010s with numbers estimated as high as 80 million or more and, therefore, companies cannot simply ignore their needs, requirements and attitudes. Based on the previous cohort, the Nexus generation has come to be defined by the characteristics formed mainly by the world and the culture in which they grew up (William J. Schroer Principal; Paper, Fitri, \& Universiti, 2016; Sally Kane, 2017).

There are a few common key aspects of the Nexus generation. However, that does not mean that all these key aspects can be found in all Millennials. The broad statements are based on an average statistical perspective. The Nexus generation is technology savvy (Lenhart et al., 2010). It grew up with technology and relies on it to perform its jobs. Growing up with smartphones, laptops and other gadgets, this generation is plugged in 24 hours a day, 7 days a week (Lenhart et al., 2010; O'Keeffee et al., 2013). It likes to communicate through email and text messaging rather than face-to-face contact and prefers webinars and online technology to traditional lecture-based presentations (Sally Kane, 2017). They were born into an interconnected world, and presume that people can and should be connected at all times (Hargittai \& Hinnant, 2008). The Millennial generation grew with strong virtual friendships and communication. A great variety of social networks, such as Facebook, Twitter and other platforms are used by them to make communications easier (Hargittai \& Hinnant, 2008; Howe et al., 2013; Sally Kane, 2017). The Millennials understand how to use Internet technology and social media and try to show the value of these modes to their parents and older members in the workplace.

The Nexus generation is family-centric (Moorthy, 2014). Nexus members are willing to trade high pay for shorter working hours and flexible time schedules to better their work-life-balances (Moorthy, 2014; Paper et al., 2016). Other generations may view this attitude as a lack of commitment or discipline, but Nexus members of the legal profession for example have a different vision of workplace expectations. They often value family upper most and it "comes first" before work (Sally Kane, 2017). The Nexus generation sees nothing wrong with taking off early or finishing important tasks at the office rather than taking them home. In an always-connected world, Millennials do not feel the need for rigid office hours to be productive (Barford \& Hester, 2011). For the Millennials, salary is in general of secondary importance. They consider work as fun and a hobby and gaining extra free time is more important (Moorthy, 2014).

Another characteristic of the Nexus generation is that it is achievement and team oriented (Hargittai \& Hinnant, 2008; Zulkifli et al., 2016). Having been nurtured and pampered by parents who didn't want to make the same mistakes as their parents, Millennials are more confident, ambitious and achievement-oriented (Solnet, Kralj, \& Kandampully, 2012). They have high expectations of their job tasks. They seek new challenges and are not afraid to question authority (San et al., 2015). The Nexus

Nur Afiqah Binti Mohammad Ishak,Nurazariah Binti Abidin and Jegatheesan Rajadurai (2019), Journal of Southeast Asian Research, DOI: 10.5171/2019. 896281 
generation desires significant work and a solid learning curve (Yunus, 2006). On the other hand, Nexus members value teamwork and seek the input and commitment of others. They are loyal and committed members. They want to be included and involved in any task. They try to avoid competition and prefer situations where there is no winner or loser, but rather a good compromise (Howe et al., 2013; Yunus, 2006).

Lastly, they crave attention and continuous development for a better future (Sally Kane, 2017). Nexus members need constructive criticism and supervision. They value being kept in a group and often need repeated commendations and encouragement (W. Horsaengchai, 2011). Millennials appreciate a mentor who can help lead and expand their talents. The disadvantage of Nexus employees is that they are always looking for something fresh and better. Their way of learning is going far beyond traditional methods. Millennials are searching for new opportunities for self development and it is not uncommon for a Millennial to stay with a firm for only two to three years before moving on to a better position perceived to be better elsewhere (Hargittai \& Hinnant, 2008; Yunus, 2006; Lifestyle, 2011). They are not afraid to change their place of employment several times, which is a clear difference between them and people of the older generations. On the positive side, working for several firms provides them with a lot of experiences (Sally Kane, 2017). The Nexus generation is constantly learning and is a better educated generation. Overall, when it comes to work values, the Nexus generation is seen as appreciating flexibility, leisure, innovation, more emphasis on a participatory management style, a balance between work and personal life and social value.

\section{Nexus Generation as Virtual Entrepreneur}

An entrepreneur is one who plays a major role in the economic development of a nation (Entrepreneurship, 2016; M. Hoppe, E. Union, 2016). Basically, an entrepreneur can be regarded as a person who has the initiative, the ability to express his/her ideas and implement their skills, and the motivation to set up a business or an enterprise of their own (Uyar \& Deniz, 2012). An entrepreneur always looks for significant accomplishments of his own or in collaboration with a team. An entrepreneur is conduit for social change and works for the common good. Entrepreneurs will look for opportunities, identify them and seize them mainly for economic profit (Uyar \& Deniz, 2012). Entrepreneurship research defines entrepreneurs as individuals who discover, evaluate, and exploit profitable opportunities (M. Hoppe, E. Union, 2016). Thus, entrepreneurs often need a new idea or knowledge, not just in a useful or tested form, but more creatively (Petkova, 2009). The characteristic of looking for opportunities, taking risks and having the courage to develop a plan through to reality, combines into a special entity that can be defined as an entrepreneur (Petkova, 2009; Uyar \& Deniz, 2012).

For anyone considering starting a business, ongoing development of entrepreneurial learning is essential to ensure he/she is being exposed to the realities of entrepreneurship and is equipped with the skills to support them when he/she starts a business (New Straits Times, MaGIC Empowers Nation's Economy, 2015; Secretariat, 2015). Entrepreneurship is a dynamic and social process wherein individuals, alone or cooperatively, identify opportunities and if necessary redesign the ideas to be practical, targeted activities in social, cultural or economical contexts (M. Hoppe, E. Union, 2016). Figure 3 sets out the five levels of learning related to entrepreneurial skills and illustrates that entrepreneurship education has five levels of skills that can be developed when studying entrepreneurship (Petkova, 2009). First is the "know why" referring to attitudes, values and motivation, "know how" is identifying abilities, while "know who" are the short and long term social abilities. The "know when" refers to long-term social skills and finally the "know what" relates to 
knowledge of the market place and goods (Petkova, 2009).

\begin{tabular}{|c|c|c|}
\hline Levels of learning & Individual & Context \\
\hline Know why & $\begin{array}{l}\text { Self-confidence, } \\
\text { motivated to achieve, } \\
\text { perseverance, acceptance } \\
\text { of risk }\end{array}$ & $\begin{array}{l}\text { Entrepreneurial spirit, sponsors, } \\
\text { models }\end{array}$ \\
\hline Know how & Technical abilities & $\begin{array}{l}\text { Complex structures on both career } \\
\text { and business levels }\end{array}$ \\
\hline Know who & $\begin{array}{l}\text { Ability to develop } \\
\text { networks }\end{array}$ & Production and social networks \\
\hline Know when & Experience and intuition & Industrial traditions \\
\hline Know what & $\begin{array}{l}\text { Encyclopaedism, } \\
\text { institutional facts }\end{array}$ & $\begin{array}{l}\text { Information networks, technical trainis } \\
\text { diversified cultural life }\end{array}$ \\
\hline
\end{tabular}

Figure 3: Five Levels of Learning of Entrepreneurial Skills

Source: Johannison. B, 1991)

However, few studies have been carried out on the traits of Nexus members as entrepreneurs (W. Horsaengchai, 2011). The unique situation for Nexus members as entrepreneurs is that they are the first generation to grow up with entrepreneurial role models (O'Keeffee et al., 2013; Yunus, 2006) such as Steve Jobs who developed the Apple company, and Mark Zuckerberg the social media sensation who developed Facebook. These role models have been enough to inspire them to join their ranks.

Next, the Nexus member is highly collaborative and team oriented (Hargittai \& Hinnant, 2008). Nexus members will pitch ideas, gain feedback from peers and display everything for the world to see and respond to. They work better in a team rather than alone (W. Horsaengchai, 2011). The main feature of the Nexus generation is that they are highly technologically savvy (Sally Kane, 2017). They came of age at the peak of the digital revolution. The Nexus members developed a unique understanding of the inner workings of the new devices which they tried to figure out through trial and error to gain knowledge (Howe et al., 2013).
Lastly, the Nexus generation member is the type who is motivated by purpose and thinking outside the box (Barford \& Hester, 2011). The Nexus member is very passionate about work but not solely about money. Nexus members are blessed with many characteristics that are unique when compared to older generations. They like thinking outside the square to learn how to do things in new and creative ways (Uyar \& Deniz, 2012). Nexus members tend to be thrilled about their jobs and they will attempt to do the job efficiently. They will not easily give up and they always learn from failure (Petkova, 2009).

Meanwhile, the virtual entrepreneur or online entrepreneur is being accepted and emerging in Malaysia (San et al., 2015). A virtual entrepreneur is a technology user with the capability of filling the world with virtual objects of their own design, with the freedom to direct their virtual experiences throughout the world (Lenhart et al., 2010; San et al., 2015). A virtual economy evolves through a user's collective efforts or contributions to create virtual objects or goods. The rise of Internet dispersion in Malaysia has created new virtual 
entrepreneurs among the Nexus generation (San et al., 2015; New Straits Times, MaGIC Empowers Nation's Economy, 2015). The Internet has become a platform for businesses and service providers to communicate information and deliver products and services to consumers (New Straits Times, MaGIC Empowers Nation's Economy, 2015). According to Turban, et al. (2009), the Internet is a useful tool to convey information to consumers as it is flexible, open, informal, and interactive. The Internet had changed the way businesses operate and the way consumers purchase goods and services (Lenhart et al., 2010). Of all the generations, Nexus is the first generation to be raised in the era of technology and social media (W. Horsaengchai, 2011; Sally Kane, 2017). Hence, the Government really needs to support the Nexus generation in becoming future entrepreneurs (Secretariat, 2015; New Straits Times, MaGIC Empowers Nation's Economy, 2015; Entrepreneurship, 2016).

\section{Conclusion}

The youth population plays an important role in this nation, so it is essential to develop and prepare our young people with attitudes, knowledge and skills necessary for Malaysia's development and economy. Furthermore, nowadays, businesses must adapt to the new realities and understand the work value of the new generation that is entering the workplace. At the same time, the digital technologies offer tremendous growth opportunities but require entrepreneurs to fully unlock their economic potential as the bases of new businesses.

To summarize, this research contributes to Malaysia's economic growth by investigating the development of job creators among Nexus members. There is growing evidence from previous studies that globally, the Nexus generation faces increasing difficulties when entering the workforce. Without the right guidance from the start, our youth will be less proficient at making choices that will improve their career scenarios and their future. The resulting effect of inadequate education, low-productivity, unemployment and the increasing poverty from one generation to the next must be identified in the Government's plan to overcome these problems (Secretariat, 2015). Hence, there is a necessity for the Malaysian government to develop strategies aimed to give young people a chance to make the most of their productive potential.

\section{Acknowledgements}

This research wishes to acknowledge the Ministry of Higher Education (MOHE) for the fund granted through the Fundamental Research Grant Scheme FRGS/1/2016/SS03/UNITEN/02/3.

\section{References}

- Lenhart, K. Purcell \& A. Smith et al (2010). Social Media and Young Adults. (pp.1-61).

- Petkova (2009). A theory of entrepreneurial learning from performance errors.International

Entrepreneurship and Management Journal (Vol 5(4), pp. 345-367).

- A. Uyar\& N. Deniz (2012). The Perceptions of Entrepreneurs on the Strategic Role of Human Resource Management. Procedia- Social and Behavioral Sciences (Vol 58, pp. 914-923).

- Zulkifli, C. Omar \& S. Rajoo (2016). Unemployment Among Graduates in Malaysia.International Journal of Economics, Commerce and Management United Kingdom (Vol IV (8), pp. 267-374).

- $\quad$ O' Keeffee, D. Thomson \& A. Dainty (2013). Understanding Generation $Y$ and their use of social media: a review and research agenda. Loughborough University Institutional Repositary (Vol 24(3), pp. 245-267).

- D. Solnet, A. Kralj \& J. Kandampully (2012). Generation Y employees:An examination of work attitude differences. Journal 
of Applied Management and Entrepreneurship (Vol 17 (3), pp. 36-54).

- Hargittai \& A. Hinnant (2008). Digital Inequality: Differences in Young Adults' Use of the Internet. Communication Research. (Vol 35(5), pp. 602-621).

- Economic Planning Unit (2015). Strengthening Infrastructure to Support Economic Expansion. Rancangan Malaysia Kesebelas (Eleventh Malaysia Plan): 2016-2020 (pp. 1-372).

- Yunus (2006). Youth employment and employability in Malaysia. Youth for Nation Building (pp. 1-15).

- Fresh Graduate Employment (2013). Reason for NOT hiring fresh graduates. Retrieved

from:http://hk.jobsdb.com/hk/en/s taticcontent/hiring-survey/2013/Q2hiring index/freshgraduateemployment.htm

- I. Barford, P. Hester (2011). Analysis of Generation Y workforce motivation using multi attribute utility theory. Defence Acquisition University (pp.18).

- J. Laird (2015). Malaysia Higher Education Blueprint 2015-2025. Hobsons Education Blog (pp. 1-25)

- Kementerian Pengajian Tinggi Malaysia (2013). Pelan Strategik Keusahawanan Institusi Pengajian Tinggi 2013-2015 (pp. 5-7)

- L. San, A. Omar, \& R. Thurasamy (2015). Online Purchase: A Study of Generation Y in Malaysia. International Journal of Business and Management (Vol 10 (6), pp. 1-7).

- Lifestyle (2011, July 20). Talkin' 'bout my label. The Sydney Morning Herald. Retrieved from: http://www.smh.com.au/lifestyle/di et-and-fitness/talkin-bout-my-label20110720-1ho7s.html
- M. Hoppe, E. Union (2016). The Entrepreneurship Concept: A Short Introduction (Vol 6(2), pp. 95108).Retrieved from:https://www.researchgate.net/publ ication/309208976_The_entrepreneurshi p_concept_a_short_introduction

- Majid, F. A., Muzlia, S., Mustafa, S., Roha, I., Jais, M., Nurul, W., .... Halim A. (2016). A Preliminary Study on Selected Malaysian Millennials: Their Characteristic and Its Implications on Teaching Innovation. 7th International Conference on University Learning and Teaching (InCULT 2014) Proceedings (pp. 685-697).

- Malaysia's National Blue Ocean Strategy(NBOS) (2016). Entrepreneurship. Retrieved from: https://www.blueoceanstrategy.co $\mathrm{m} /$ malaysia-nbos/entrepreneurship/

- N. Howe, W. Strauss \& P. Center et al (2013). Generation Y values and lifestyle segments. Journal of Consumer Marketing. (Vol 30 (7), pp. 22-26).

- National Blue Ocean Strategy (NBOS)(2015, July 13). MaGIC Empowers Nation's Economy. New Straits Times. Retrieved from: http://www.nst.com.my/

- News Malaysia (2015, October 26). Future graduates will be job creators, not job seekers- Idris Jusoh. Astro Awani. Retrieved from: http://english.astroawani.com/malaysian ews/future-graduates-will-be-jobcreators-not-job-seekers-idrisjusoh-78039

- P. Secretariat (2015). National Youth Policy Towards 2020 A shared vision for the future. National Youth Policy Towards 2020 (pp. 1-26).

- R. Moorthy (2014). An Empirical Study of Leadership Theory Preferences among

Nur Afiqah Binti Mohammad Ishak,Nurazariah Binti Abidin and Jegatheesan Rajadurai (2019), Journal of Southeast Asian Research, DOI: 10.5171/2019. 896281 
Gen Y in Malaysia. Bus. Econ. Res. Online (Vol 3 (2), pp. 2304-1013).

- S. By, T. Prime, \& I The et al (2016). Speech By the Prime Minister Eleventh. RMK11_Speech (May 2015, pp.

1 40).

- Sally Kane (2017). Common Characteristics of Generation Y. Retrieved from:

https://www.thebalance.com/comm on-characteristics-of-generation-yprofessionals-2164683

- $\quad$ Shamsudin, S. F. F., Mamun, A. Al, Nawi, N. C., Nasir, N. A. M., \&Zakaria, M. N. (2006). Policies and Practices for Entrepreneurial Education in Malaysia: A Review. Mediterranean Journal of Social Sciences (Vol 15 (4), pp. 36-41).

- SyahiraSa'aban, Noraisah Ismail \& Mohd Fitri Mansor (2013). A STUDY ON
GENERATION Y BEHAVIOR WORKPLACE. International Conferenceon Business Innovation, Entrepreneurship and Engineering 2013(ICOBIEE2013) (pp. 7).

- United Nation (2002). Youth in Malaysia: A Review of the Youth Situation and National Policies and Programmes.

Economic and Social Commission for Asia and the Pacific (pp. 1-106).

- W. Horsaengchai (2011). Are Millennials Potential Entrepreneurs? Retrieved from: http://www.divaportal.org/smash/g et/diva2:426723/FULLTEXT01.pdf

- William J. Schroer Principal. Generation X, $\mathrm{Y}, \mathrm{Z}$ and the others. Retrieved from:http://socialmarketing.org/arc hives/generations-xy-z-and-the-other

Nur Afiqah Binti Mohammad Ishak,Nurazariah Binti Abidin and Jegatheesan Rajadurai (2019), Journal of Southeast Asian Research, DOI: 10.5171/2019. 896281 